\title{
Transylvania in German Newspapers Systems of Reporting and the News Stories of György II Rákóczi, 1657-1658
}

\section{Virginia Dillon}

Following the end of the Thirty Years' War, the continent of Europe did not fall into a settled peace, and one of the largest and longest-lasting conflicts was the series of military and political struggles now known as the Northern Wars. The rotating cast included Sweden, Denmark, the Cossacks, the PolishLithuanian Commonwealth, Russia, Prussia, and, for one year, György II Rákóczi, Prince of Transylvania. Though Rákóczi entered the war in January 1657 with the dream of a Transylvanian wearing the crown of Poland, by December he was fleeing from the Tartars to a diet that awaited his resignation. The year 1658 only saw further decline for Transylvania, as Ottoman forces marched through the principality, reasserting their control.

The stories of Transylvania during this two-year period offer an interesting example of many of the topics that appear in seventeenth-century news. A country which invades its neighbour is then subject to an invasion itself; a prince claims authority in a foreign land and then has his own power taken from him in his home country; Calvinists fight Catholics, then Tartars and Turks; and all the while Transylvania is rarely the author of its own news, but rather the subject of reporting by regions which are often less than friendly. This dynamic affects both how news is covered, and even what news is considered worthy of attention.

The news of Transylvania came not only via the nearest news centre in $\mathrm{Vi}$ enna with ties to Hungary, but also through the Polish-Prussian system in the north, with each system concentrating on those events which most affected the reporting region, rather than demonstrating any more general interest in Transylvania. As a result, the two waves of events - the invasion of Poland by Rákóczi in 1657 and the invasion of Transylvania by the Ottomans in 1658 - are told from different perspectives. This paper will first explore these two reporting systems, defining which cities report news of Transylvania, and further, which locations are cited as a source of the information conveyed. Afterwards, the subjects of politics, religion, and violence will be examined, and distinctions drawn about the selection of events covered and patterns in language usage for each reporting location. From the Prussia-Poland system comes news of Rákóczi's march, littered with words describing acts of violence, prayers to 
God for protection, and accompanied by promises to preserve the rights of the population. From the Vienna-Hungary system comes news of the struggle for authority within the principality, conveyed with fewer words of violence, but more references to the participants' religious affiliation and the need to preserve Christendom. The reporting location of news of Transylvania determines not only what political news is related, but also how religion is incorporated into the story, and how frequently violent words are employed.

\section{Systems of Reporting}

The principality of Transylvania and its leaders are the subjects of 577 different news reports during the years 1657-1658, but only rarely do these reports come from the region itself. Rather, news of Transylvania is reported chiefly by two different reporting systems. These systems are defined here by the locations cited both in the reports' datelines and any references made to a source of news within the text. (Map 3.1). ${ }^{1}$

The most frequent reporting location is the city of Vienna, which offers 178 news reports, or $31 \%$ of the total number of reports. ${ }^{2}$ While no other single city generates anywhere near that number, if neighbouring cities are considered together as a reporting region rather than individually, the numbers of reports in each grouping are more equal (see Table 3.1). With this reorganization, the cities of Polish Prussia - including Elbing (50), Thorn (48), Marienburg (33), and Danzig (23) - rival the contribution of Vienna. Furthermore, the reports from the Habsburg Hereditary Lands outside of Vienna - including Silesia (31), Prague (27), and Breslau (23) - have a much more significant presence. ${ }^{3}$ The Polish-Lithuanian Commonwealth, the German lands, and the allied Swedish and Brandenburg Baltic territories (including Königsberg (17)), are roughly comparable, while the combined region of Hungary and Transylvania is nearly equal to that of the cities linked by the Mediterranean Sea. ${ }^{4}$

1 This is not to deny the systems' infrastructural basis, but rather to note that this aspect will not be a subject of this paper. For more on the postal system, which is of obvious importance to the communication of news, see Wolfgang Behringer, Im Zeichen des Merkur: Reichspost und Kommunikationsrevolution in der Frühen Zeuzeit (Göttingen: Vanerhoeck \& Ruprecht, 2003).

2 A full list of the extant newspapers in the German language, their publication information, and the surviving issues from 1657-1658 is given at the end of the chapter (see p. 75).

3 In order to preserve continuity with the German-language newspapers, the names of all cities are given in German.

4 For the purposes of brevity and clarity, this paper will concentrate on the news from the major reporting centers of Vienna, Prussia, and the Hereditary Lands, as well as those 


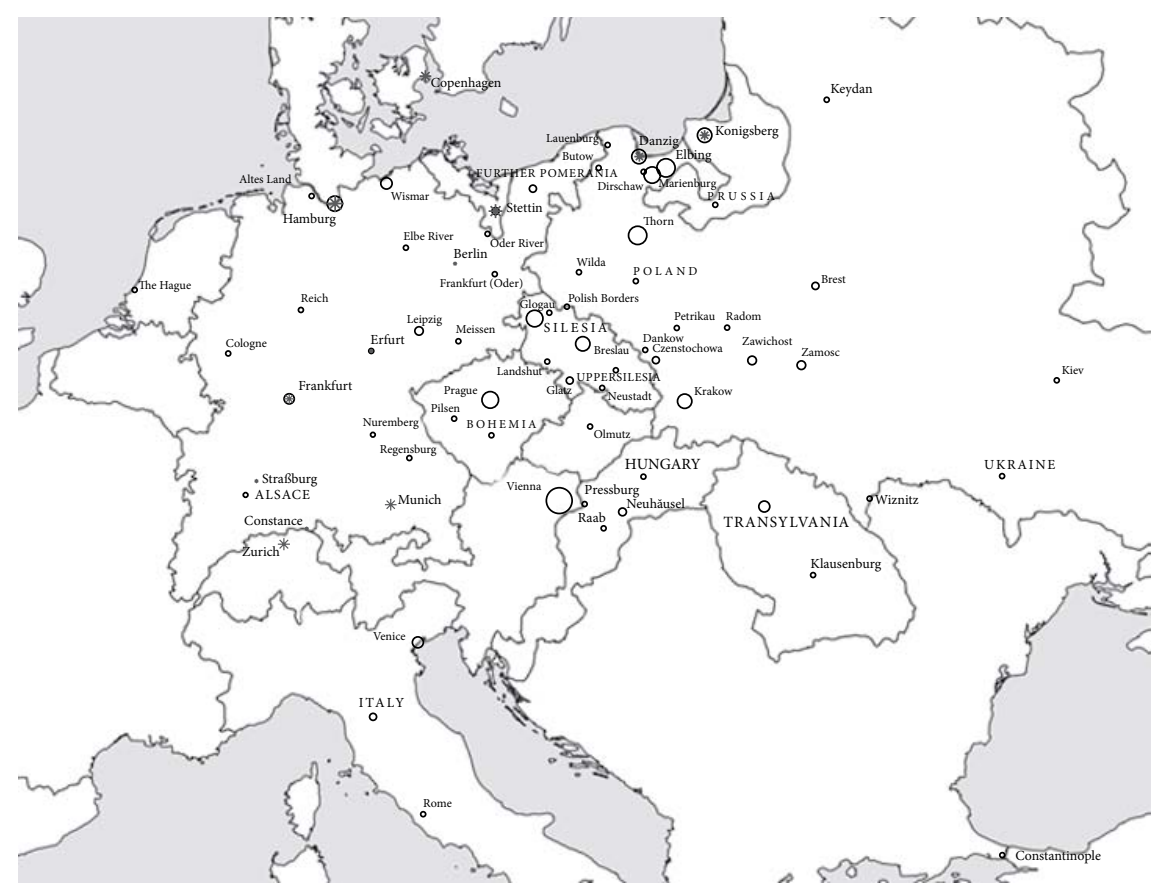

MAP 3.1 Map indicating with a star the location of German-language newspapers with extant issues from 1657-1658, and indicating with a circle the reporting locations for the news of Transylvania (size of circle demonstrates number of reports)

These reports generally break down into three story subjects: those which relate to Rákóczi's invasion of Poland and its consequences; those which focus on the conflicts and negotiations between the Transylvanian princes and the Ottoman Porte; and the reactions within Hungary to these events. ${ }^{5}$ By looking at reporting region and story subject, several patterns are immediately apparent. The neighbouring regions of the Polish-Lithuanian Commonwealth, Prussia (both Polish and Brandenburg-Swedish), and the Hereditary Lands, are more likely to report on Rákóczi's involvement in Poland. The Ottomans, however, are more frequently the subject of news reports from Vienna, the Mediterranean, and the reporting region of Hungary-Transylvania.

From these reporting locations, references within the news text itself can give a more subtle understanding of how news of Transylvania is circulated.

locations giving reports of local occurrences, Hungary and Transylvania, and PolandLithuania.

5 Because each report can contain news on more than one subject, on a few occasions reports contain more than one type of story. Thus, there are more stories than reports. 
TABLE 3.1 Number of reports originating in each region, subdivided by story subject

\begin{tabular}{lrrrr}
\hline \multirow{2}{*}{ Reporting region } & Reports & Story subject & \\
\cline { 2 - 5 } & Total & Poland & Ottomans & Hungary \\
& & & & \\
\hline Vienna & 178 & 45 & 113 & 32 \\
Polish Prussia & 157 & 150 & 4 & 2 \\
Hereditary Lands & 91 & 65 & 21 & 5 \\
Poland-Lithuania & 45 & 45 & 2 & 0 \\
German Lands & 41 & 17 & 22 & 3 \\
Brandenburg-Swedish Prussia & 33 & 24 & 6 & 2 \\
Mediterranean & 14 & 1 & 11 & 2 \\
Hungary \& Transylvania & 12 & 1 & 11 & 0 \\
Other* & 6 & 3 & 3 & 0 \\
Total & 577 & 351 & 193 & 46 \\
& & & & \\
\hline
\end{tabular}

* The category 'Other' includes 3 reports whose reporting location is unknown, 2 reports from The Hague and 1 from Alsace.

These in-text references to the source of the news may only be an allusion to a report received or rumour heard, but occasionally news is cited as coming from a specific location, brought by an official messenger or envoy, through travellers and merchants, or via manuscript letters. By adding these details to our reporting locations, a more nuanced web of news sharing emerges.

The first major reporting system is centred on the city of Vienna. During this period, the reports from Vienna frequently note that information on Transylvania comes from either Hungary (45), a land under the Imperial crown, or Transylvania itself (23). Additionally, there are occasional reports from the other regions participating in the conflicts: Poland (5) and the Ottoman Empire (6). The references made to news from Hungary rarely designate a specific medium through which the news is transmitted, simply noting that a report comes from Hungary, while news from the other regions often travels via a designated messenger or envoy, such as a Polish emissary or a Turkish chiaus. ${ }^{6}$

6 "Aus Ungarn kompt Bericht," “Aus Wien/vom 26. Junii." HPZ:Sa, Hamburg 1658, no. 28; "Wien vom 2.12. Dito" [April] WZ:Do, Hamburg 1657, no. 17; "Auß Wien/vom 25. April" OWP, Frankfurt 1657, no. 19. 
The second major reporting system is based around the reporting centres of the Baltic, and Polish and Brandenburg-Swedish Prussia. A large number of reports from Polish Prussia originate in the cities and villages of the PolishLithuanian Commonwealth (20), as well as occasional reports from representatives of the King of Sweden (5) and the Prince of Transylvania (4) as they march through the country. This news is brought by a variety of individuals, primarily connected to the military, including both Swedish officers and Polish cavalry captains. ${ }^{7}$ News also frequently circulates within the region itself (16), with Thorn in particular being a source commonly cited in-text (12). Similarly, the reports from Brandenburg-Swedish Prussia also cite news as coming primarily from the region of conflict, particularly via military sources. News is attributed to communications from Poland-Lithuania (3), the Scandinavian armies (3), Transylvania (1), and Hungary (1), as well as Polish Prussia (2), the Hereditary Lands (2), and Vienna (1).

These two reporting systems are not discrete entities and the reporting region of the Hereditary Lands offers a point of intersection. This region includes the lands of Silesia, Bohemia, and Moravia, all of which were ruled by the Habsburg emperor under the title King of Bohemia. However, the region of Silesia in particular also had strong economic and cultural ties with its neighbor, Poland-Lithuania. Consequently, the reports from this region contain a large number of references to news from Poland-Lithuania (17), as well as some references to sources from Vienna (4), the German Lands (3), and the armies of Sweden and Denmark (3), among others. This news is brought by civilian travellers and merchants in addition to the military personnel: "some merchants from Russe and Zamość," “a good friend from Tarnowitz," "a colonel coming from Poland," "several Scots and passengers from Lemberg," and "an engineer from the Royal Hungarian camps."

News of Transylvania rarely comes from the principality itself, rather information travels from outside sources via two reporting systems. The first is news printed in newspapers directly from Vienna, commonly citing Hungary or

7 “Thorn vom 7. Dito" [April] WZ:Do, Hamburg 1657, no. 15; "Elbingen vom 4. 14. Dito" [August] WZ:Do, Hamburg 1658, no. 34.

8 In the original: "einige Kauffleute aus Reussen und Samoisce," "Extract Schreibens aus Bresßlaw vom 17. Dito" WZ:Di, Hamburg 1657, no. 10; "ein guter Freund von Tornawitz 12. Meil von Crakow liegend," "Breßlaw vom 7. April” WZ:Di, Hamburg 1657, no. 16; "auß Polen kommender Obrister," “Aus Praag/vom 23. Junii." HPZ:Sa, Hamburg 1657, no. 27; "etliche Schotten und Passagieri/so von Lemberg," "Auß Schlesien/vom 1. 11. Augstmonat." NZR, Zurich 1657, no. 34; "ein Ingeneur aus dem Königl. Hungarischen Läger," “Breßlaw vom 8. 18. Dito." [August] WZ:Di, Hamburg 1657, no. 35. 
envoys as the source of information. The second is a broader spreading of news from the Polish-Lithuanian Commonwealth, either directly to the newspapers, or through Prussia and the Hereditary Lands. Polish Prussia, in particular, then circulates news within the region, with the cities of Thorn, Danzig, and Marienburg acting as both reporters of news and as sources cited within the news reports. ${ }^{9}$ Each reporting system, Vienna-Hungary and Prussia-Poland, report the news of Transylvania that is of greatest interest to their own regional concerns. From Prussia-Poland comes, almost exclusively, news of the Rákóczi's Polish invasion. From Vienna-Hungary comes a greater concentration of news reports concerning the Ottoman advance and the domestic issues of Hungary.

\section{Political News}

Over the course of only two years Rákóczi falls from being a prince with aspirations to the throne of Poland, to having his own title revoked by his diet and two different men elected in his place. While the story can now be told as a cohesive narrative, in the newspapers of the time each turn of events was related from a different perspective. Poland, Prussia, and the Hereditary Lands related occurrences within Poland; while Vienna, Hungary, and Transylvania concentrated on political events within the principality itself, particularly as they related to the Ottomans. The concerns of each reporting region, rather than any overarching interest in the affairs of the principality, dictate what is communicated about Transylvania and printed in the newspapers.

The story of the Polish invasion that led to Rákóczi's eventual political downfall begins with the signing of the Treaty of Radnot with King Charles X Gustav of Sweden on 6 December 1656. With this alliance, Rákóczi promised Sweden military support, and Sweden offered Rákóczi the crown of PolandLithuania, as long as the current king of Poland, John II Casimir Vasa, did not successfully return from his exile in the duchy of Opole-Racibórz in Upper Silesia to reclaim it. Soon after, Rákóczi also formed an alliance with the Zaporozhian Cossacks who had been rebelling against Casimir since 1648.10 Both of these events were recounted in reports from nearly every reporting region, with particular attention paid by the cities of Brandenburg and Swedish

9 Thorn is cited 14 times in other news stories from within Polish Prussia, Danzig is cited 5 times, and Marienburg, twice.

10 For more see Robert Frost, The Northern Wars: War, State and Society in Northeastern Europe, 1558-1721 (Harlow: Longman, 2000), pp. 156-191. 
Prussia, as well as a detailed account of the terms of the Treaty of Radnot from the city of Thorn. ${ }^{11}$

Once the Transylvanian army crossed into the Polish-Lithuanian Commonwealth, news from Poland became of central importance. News of the entrance of Rákóczi into the cities of Lemberg, Krakow, and Brest came from the cities themselves or those nearby, and recounted the promise that the prince came "as a friend, and not as an enemy" and would protect noble rights. ${ }^{12}$ Reports from Polish Prussia also contain promises from Rákóczi that his reign as king would be as blessed as that of István Báthory.13

Though Rákóczi's march was initially successful, his luck changed in the summer of 1657 when Charles turned the Swedish troops north to confront the Danish army which had recently declared an alliance with Casimir. Rákóczi, left without his strongest ally and facing a population which did not support his claim to the throne, signed a humbling peace treaty and returned to Transylvania. This disappointing outcome of Rákóczi's attempt to claim the crown of Poland received attention, not only from the cities of Prussia and Poland-Lithuania, but also from the Hereditary Lands, albeit in less detailed reports. ${ }^{14}$ After the peace is signed and Rákóczi returns to Transylvania, the cities of Poland and Prussia largely stop reporting on political events in

11 "Thorn vom 14. Martii. 1657." EZ:PS, Stettin 1657, no. 12.

12 One report states that a trumpeter from Rákóczi to Lemberg announced "Er kähme als ein Freund/und nicht als ein Feind," "Extract Schreibens auß Samoiscie den 25. Jan. 1657." EZ:App, Stettin 1657, no. 7. There are also reports from Krakow and Brest: "Crakow vom 5. April." WZ:Do, Hamburg 1657, no. 17; "Kurtzer Bericht Welcher gestalt der feste Orth Brescie Litewsky von Ihrer Königl. Majest. zu Schweden/rc. rc. und dem Fürsten von Siebenbürgen per Accord ohne Verlust eines eintzigen Manns erobert worden/sampt denen daselbst getroffenen Accords-Puncten. [...] Gegeben im Königl. Hauptquartier Ostrozana den 14. 24. Maii 1657. Folgen die Accords Puncta. [...] Gegeben im Feldlager bey Brzescie den 6. 16. Maii. 1657." WZ:Do, Hamburg 1657, no. 23.

13 Báthory was a Transylvanian prince who was king of Poland in the sixteenth century. "Elbingen vom 6. 16. Febr." WZ:Do, Hamburg 1657, no. 8; “Copia eines vertrawten Schreibens aus Dantzig an einen Churfürstl. Brandenburgischen Bedienten sub dato 6. Januarii." WZ:App, Hamburg 1657, no. 3; "Elbingen vom 2. Dito." [March] WZ:App, Hamburg 1657, no. 10.

14 Such as "Auß Schlösien vom 15. 25. Augstm." NZR, Zurich 1657, no. 36; "Aliud ab eodem" [Breslau, 17 February] WZ:Do, Hamburg 1657, no. 9; "Breßlaw vom 9. Dito" WZ:Do, Hamburg 1657, no. 13. The conditions of the peace are enumerated in "Aus Pilza/vom 12. Julij." ZAH, Copenhagen 1657, no. 29. Other reports include "Marienburg vom 11. 21.Augusti 1657." EZ:PS, Stettin 1657, no. 33. “Dantzig vom 11. Augusti." ZAH, Copenhagen 1657 , no. 33 . 
Transylvania. ${ }^{15}$ Their interest was primarily regional, and once the prince marches out of their country he is no longer a great concern, even with the political upheaval that is about to take place across the border.

The next wave of events is largely reported from Hungary, Vienna, and Transylvania, and had actually begun while Rákóczi was still in Poland. The prince's march into a foreign country had upset the Ottoman Porte, to which Transylvania had owed suzerainty since the sixteenth century. Though the principality had been largely autonomous in internal matters, Rákóczi's military action had not been approved by the sultan, and the Ottomans now wanted the prince dismissed from his position. The Porte sent the Crimean Tartars into Poland to intercept Rákóczi's army, and the prince's attempts to avoid confronting them were unsuccessful. When the Transylvanians and the Tartars met, Rákóczi abandoned his troops and quickly fled to Transylvania.

When Rákóczi returned, he found the diet in Weißenburg (present day Alba Iulia, Romania; Gyulafehérvár in Hungarian) had received orders from the Ottoman Grand Vizier Mehmed Köprülü to immediately revoke his title of Prince of Transylvania and to elect Ferenc Rhédey in his stead. Though Rákóczi initially accepted his dismissal, he soon changed his mind and attempted to retake his position. In response, the Ottomans sent troops into the principality to reassert their authority. In the autumn of 1658, Ákos Barcsai approached Köprülü with promises of loyalty, and, in return, became the third prince of Transylvania in a year, a position confirmed by the diet in October. The most detailed descriptions of these events came in reports from Hungary and Transylvania, but the meetings of the diets were also of particular importance to Vienna. ${ }^{16}$ The Holy Roman and Ottoman Empires had fought a series of wars in the sixteenth century, and, with the Ottoman army once again marching near the Hungarian borders, Vienna is inspired to pay increased attention to Transylvanian political affairs. ${ }^{17}$ Transylvania is in a precarious position,

15 There are a few reports from Poland and Prussia on the story subjects of the Ottomans and Hungary (see Table. 3.2), but these are only a small fraction of the number that had appeared when Rákóczi was marching in Poland-Lithuania.

16 “Aus Newhäusel vom 21. Novemb." WZ:Di, Hamburg 1657, no. 53; “Aus Siebenbürgen vom 27. Decemb." WZ:Do, Hamburg 1658, no. 4; "Siebenbürgen vom 27. Dito." [September] WZ:App, Hamburg 1658, no. 44.

17 There are numerous reports from Vienna which include of news of the political situation in Transylvania, some in detail, some only briefly. A sampling of these stories which concentrate on the proceedings of the Transylvanian Estates and the Hungarian Diet include: “Wien vom 19. Dito." [Dec.]WZ:Do, Hamburg 1658, no. 1; “Aliud ab eodem” [Vienna, 12. December] WZ:Do, Hamburg 1657, no. 52; "Wien vom 28. Dito." [November] WZ:Do, Hamburg 1657, no. 50; “Wien vom 28. Novemb." WZ:App, Hamburg 1657, no. 50; 
balanced between these two great empires, and if it becomes politically unstable or if the Ottomans seize a firmer control of both the government and the fortresses along the borders, Vienna fears for its own safety and for that of all Christendom.

\section{Allusions to Religion}

The different reporting systems not only affect the primary subject of the news story - i.e. whether the news is of a meeting of the Hungarian Diet or justification for claiming the crown of Poland-Lithuania - but also its corollary subjects. In these reports on Transylvania, religion is rarely the primary focus of a story; rather, it appears through the use of words that are religious in association, within the wider context of narratives of political or military events. These words largely fall into four categories: affiliation (e.g. Christian, Catholic, Reformed), God, the Church, and words with more general religious connotations. These latter two categories are used fairly equally by the two major reporting systems: both Vienna-Hungary and Prussia-Poland reference the people, places, and days associated with the organized Church (e.g. references to priests, churches, Pentecost), and use language which carries general religious associations (e.g. soul, divine, blessed). However, Prussia-Poland is much more likely to offer prayers or supplications to God within the reports of the Transylvanian army, while Vienna-Hungary identifies people, armies, and lands as 'Christian' in the face of the Ottoman invasion (see Fig. 3.1).

References to the people, buildings, and days associated with the Church largely appear in the stories of Rákóczi's invasion of Poland and are included in reports from both the Prussia-Poland and Vienna-Hungary reporting systems. From Prussia-Poland, allusions to the Church include remarks on the King of Sweden's day of repentance, the cloister of Częstochowa, and the Bishop of Lemberg, as well as more general references to priests and noblemen. ${ }^{18}$ From Vienna, there are three references to the upcoming Pentecost telling of Rákóczi's imminent departure from Transylvania to begin his

\footnotetext{
"Extract Schreibens aus Wien vom 3. 13. Febr." WZ:Di, Hamburg 1658, no. 9; "Aliud ab eodem" [Vienna, 28 September] WZ:App, Hamburg 1658, no. 41; "Aus Wien den 30. October" ZAH:R, Copenhagen 1658; “Aus Wien vom 6. Novemb.” WZ:Do, Hamburg 1658, no. 47.

18 "Kurtzer Bericht Welcher gestalt der feste Orth Brescie Litewsky..." WZ:Do, Hamburg 1657, no. 23; "Marienburg vom 14. 24, Dito" [April] WZ:Di, Hamburg 1657, no. 18; "Extract Schreibens auß Samoiscie den 25. Jan. 1657" EZ:App, Stettin 1657, no. 7; “die Pfaffen und Edelleute' Crakow vom 5. April" WZ:Do, Hamburg 1657, no. 17.
} 


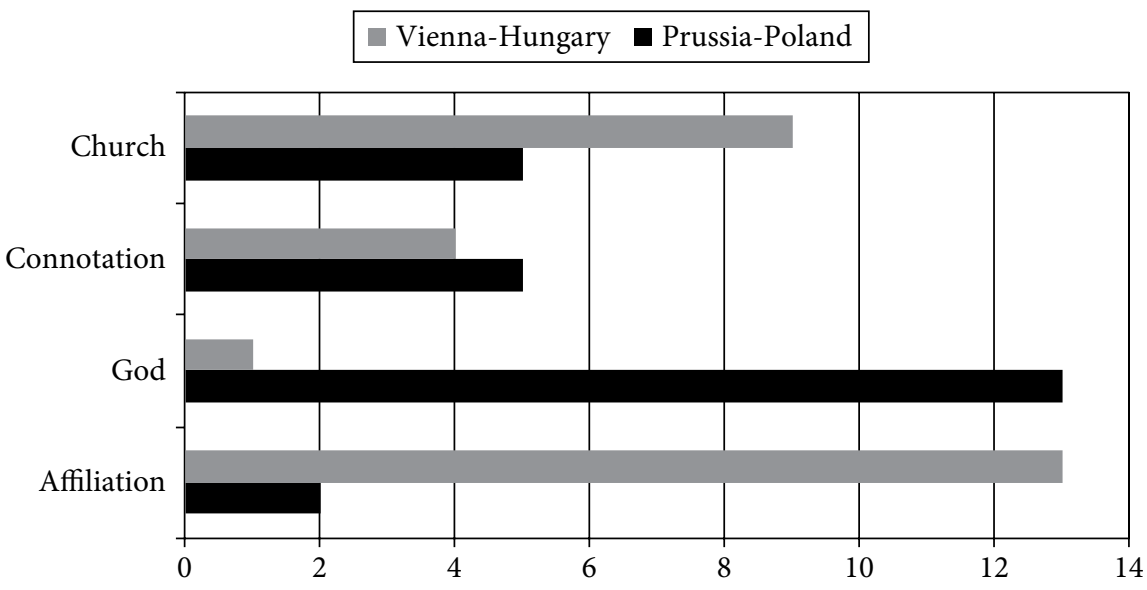

FIGURE 3.1 Number and types of religious references from each reporting system

march into Poland, and a Hungarian bishop recently sent by the Emperor as an envoy to Rákóczi. ${ }^{19}$ Additionally, in the news from Poland the words göttlich (Godly), segnen (bless), and Oration appear, and from Elbing, glückselig (blessed). ${ }^{20}$

The most remarkable aspect of the news from Prussia-Poland in this regard is the repeated prayers made as Rákóczi leads his Transylvanian and Cossack troops northward in Poland. Of the 25 references to religion in the reports from this reporting system, half are uses of the word 'God': "Praise God!," "Thank God," "God grant that which is good," "God help further," and more are all exclaimed in the reports from Poland. ${ }^{21}$ Of these, six come from the Polish-Lithuanian Commonwealth, five from Polish Prussia, and one from Brandenburg Prussia. This use of prayer to or praise of God from cities facing

19 "Aus Wien vom 5. Februarii” WZ:Di, Hamburg 1657, no. 8; "Aus Wien vom 7. Februarii” WZ:Do, Hamburg 1657, no. 8; "Deutschland. Wien vom 10. Feb. st. n." EZ:App, Stettin 1657, no. 8; “Deutschland. Wien vom 10. Feb. st. n." EZ:App, Stettin 1657, no. 8.

20 "Eigentlicher und glaubwürdiger Bericht... sub dato in dem Königl. Schwedischen Hauptquartier Zavicost den 6. Aprilis Anno 1657” WZ:Do, Hamburg 1657, no. 21; “Kurtzer Bericht Welcher gestalt der feste Orth Brescie Litewsky...” WZ:Do, Hamburg 1657, no. 23; "Crakow vom 5. April" WZ:Do, Hamburg 1657, no. 17; “Elbingen vom 6. 16. Febr.” WZ:Do, Hamburg 1657, no. 8.

21 "Gott Lob!" and "Er Gott gedancket," "Elbing vom 10. April. 31. Mart." EZ:AppPS, Stettin 1657, no. 14; "Gott gebe was gutes," "Aliud ab eodem" [Elbing, 13 April] WZ:Di, Hamburg 1657, no. 16; "Gotte helffe ferner," "Extract Schreibens aus Crakow vom v. Febr." WZ:Di, Hamburg 1657, no. 10." 
marching armies reflects an urgent need, a sense of hope or desperation, and gives a sense of immediacy to the events being reported.

Though reporting on the military invasion of a Catholic country by a Reformed prince, there are very few references to religious affiliation within the stories of Prussia-Poland. Furthermore, only one of the references made to affiliation is in the context of Rákóczi's advance: the aforementioned promise to repeat the blessed reign of Báthory (see page 64) and Rákóczi's promise to accommodate the Polish customs and assume their religion. ${ }^{22}$ Whether Rákóczi would have fulfilled his bold declaration to embrace the Catholicism of both Poland and Báthory is unknown given his eventual defeat, but it is remarkable that concern for the denominational difference between invader and invaded is only mentioned on one occasion in the 351 reports of the Transylvanian march.

The other reference to religious affiliation from Prussia-Poland comes in the context of another prince of Transylvania making claims for authority, but this time concerning the struggles in the principality. Both a report from Prussia and a report from Vienna describe Rhédey as "a lord of good understanding, the Reformed religion, and middle age" on the occasion of his election to the title of Prince of Transylvania. ${ }^{23}$ Barcsai is similarly described in a report from Vienna when he becomes the third named Prince of Transylvania in a year. ${ }^{24}$ In the context of the election of the prince of Transylvania, being of the Reformed religion is recognized as merely a common characteristic and is not presented as an association necessitating unease.

By far the most frequently appearing denotation of religious affiliation is that used by Vienna-Hungary as the Ottomans march into Transylvania: 'Christian'. Of the 27 uses of religious language in the stories from Vienna, Hungary, and Transylvania, 11 are of the words Christen (Christians), Christenheit (Christianity or Christendom), or Christlich (Christian). All five of the references in stories from Hungary and Transylvania, and half of those in the stories from Vienna, use these identifiers: for example, "many captured Christians and Hungarians killed," "the Christians on the borders," or "a great number of

22 "daß Er ad exemplum Stephani Battori, den Pohlnischen Sitten sich accommodiren und ihre Religion annehmen würde," "Copia eines vertrawten Schreibens aus Dantzig an einen Churfürstl. Brandenburgischen Bedienten sub dato 6. Januarii” WZ:App, Hamburg 1657 , no. 3 .

23 "einen Herrn von gutem Verstande/der Reformirten Religion/und mittelmässigen Alters," "Dantzig/vom vorigen” [December] EWZ:So, Königsberg 1658, no. 1; “Wien vom 28. Novemb.” WZ:App, Hamburg 1657, no. 50.

“Auß Wien/vom 20. 30. Weinm.” NZR, Zurich 1658, no. 44. 
Christians kidnapped by the Barbarian people."25 This usage clearly underscores the unchristianness of the Ottoman Turks, and in the case of reports from Vienna, gives an excuse for sympathy with a country that is more commonly the enemy than the ally. This is further supported by the use of Seelen (souls) to describe the Hungarian and Transylvanian people killed or captured by the Turks. ${ }^{26}$ While in the case of Rákóczi's invasion of Poland there is apparently little need to highlight the religious differences of a Reformed prince in a Catholic country, when the Muslim Turks marched into region that acted as a buffer to Christendom, Christianity becomes a unifying characteristic.

Despite the apparent concern from Vienna, Hungary, and Transylvania for the fate of Christendom as the Ottomans advance northwards, their stories contain only one reference to God: "God see to Christendom."27 The inclusion of prayers within the news stories of 1657-1658 is a habit resting only with the cities of Poland and Prussia. While the two reporting systems may both include words with religious connotations and references to the Church, religious language is not uniform throughout the news of Transylvania. Reports from Vienna-Hungary are considerably more likely to invoke the differences in religious affiliation between the Ottoman army and the Transylvanian principality, while Prussia-Poland communicates its apprehension through prayers made for protection and thanksgiving.

\section{Language of Violence}

The above analysis of religious language largely ignores the reporting region of the Hereditary Lands as the 91 reports from this region include only two references to religion: the twice-appearing phrase that "much evil has proceeded against the clerics and nobles." ${ }^{28}$ In neither of the stories of Rákóczi's march

25 "viel gefangene Christen und Ungarn erlediget," "Auß Siebenbürgen vom 10. 20. Novemb." EZ:DiPS, Stettin 1658, no. 50; "die Christen an den Gräntzen," "Wien vom 6. Decemb." $W Z: D i$, Hamburg 1657, no. 51; "was für ein grosse anzahl Christen von gedachten Barbarischen Völckern entführet," “Wien vom 30. Octob." WZ:App, Hamburg 1658, no. 46. "die Türcken in die 60,000. Seelen aus Siebenbürgen nach der Türckey weggeführet," "Wien vom 30. Dito" [October] WZ:Do, Hamburg 1658, no. 46; “Wien vom 8. Dito" [May] WZ:Do, Hamburg 1658, no. 46.

27 "Unsere Gräntzen seynd wol versehen/und warden uber das je länger je besser verwahret/ Gott siehe der Christenheit bey," “Wien vom 6. Martii.” WZ:App, Hamburg 1658, no. 12.

28 "wider die Geistlichen unnd Edelleut sehr übel verfahren." "Schlesien vom 14. Dito" [April] WZ:Di, Hamburg 1657, no. 18; "Auß der Schlösien/vom 24. April" RAF, Strassburg 1657, no. 18. 
into Poland, nor the Ottoman advance into Transylvania, are religious affiliations referenced or prayers to God proclaimed. What does mark the stories from the Hereditary Lands is language describing violent acts. It is not the frequency of this usage that is remarkable - these words are no more or less common in the Hereditary reports than in the reports from the two main reporting systems - but their subject area. The violence in these stories appears primarily in reports from Breslau and Silesia and almost exclusively describes the events in Poland. The economic and cultural ties of the region, rather than the political concerns of the Habsburg Emperor, affect which war gains the most attention in reports from these lands.

The language of violence, as considered in this chapter, includes direct descriptions of violent acts or common modifiers. These words detail the willful death of another individual, the destruction of property, and the stealing of goods: all actions that are perpetuated by individuals and groups. Not included in this consideration are those words that communicate acts which take place between armies, such as 'invade', 'attack', or 'besiege'. The sixty words designated as 'violence words' are divided here into four categories based on frequency of usage (see Table 3.2). ${ }^{29}$

TABLE 3.2 Vocabulary describing violence in the news stories of Rákóczi, organized by frequency of usage

\begin{tabular}{|c|c|c|c|}
\hline$A(10+)$ & B (5-9) & C (2-4) & $\mathrm{D}(1)$ \\
\hline $\begin{array}{l}\text { Schaden, } \\
\text { damage (23) }\end{array}$ & $\begin{array}{l}\text { niederhauen, to } \\
\text { hew-down (9) }\end{array}$ & $\begin{array}{l}\text { plündern, to } \\
\text { plunder (4) }\end{array}$ & $\begin{array}{l}\text { abschneiden, } \\
\text { to amputate }\end{array}$ \\
\hline $\begin{array}{l}\text { Gewalt, } \\
\text { violence }(20)\end{array}$ & $\begin{array}{l}\text { schießen, } \\
\text { to shoot }(9)\end{array}$ & $\begin{array}{l}\text { beängstigen, } \\
\text { frighten (3) }\end{array}$ & $\begin{array}{l}\text { entführen, } \\
\text { to kidnap }\end{array}$ \\
\hline $\begin{array}{l}\text { niedermachen, } \\
\text { to massacre }(20)\end{array}$ & Beute, booty (8) & Blut, blood (3) & $\begin{array}{l}\text { enthaupten, } \\
\text { to behead }\end{array}$ \\
\hline $\begin{array}{l}\text { brennen, } \\
\text { to burn (16) }\end{array}$ & Furcht, dread (8) & erlegen, to slay (3) & erstechen, to dagger \\
\hline Ruin, ruin (15) & $\begin{array}{l}\text { Bedrohung, } \\
\text { threat ( } 7)\end{array}$ & $\begin{array}{l}\text { sprengen, } \\
\text { to burst (3) }\end{array}$ & Furie, fury \\
\hline
\end{tabular}

29 The selection and classification of words in this list are based on the author's own analysis of the text. Violence words with the same root appear together, e.g. Raub (robbery) and rauben (to rob) are both counted under the word rauben. 
TABLE 3.2 Vocabulary describing violence in the news stories of Rákóczi, organized by frequency of usage (cont.)

\begin{tabular}{|c|c|c|c|}
\hline$A(10+)$ & В (5-9) & C (2-4) & $\mathrm{D}(1)$ \\
\hline $\begin{array}{l}\text { verfolgen, } \\
\text { to chase }(14)\end{array}$ & Tod, dead (7) & $\begin{array}{l}\text { umbringen, } \\
\text { to kill (3) }\end{array}$ & Lunte, fuse \\
\hline übel, evil (12); & ernst, severe (5) & $\begin{array}{l}\text { anzünden, } \\
\text { to ignite (2) }\end{array}$ & morden, to murder \\
\hline Feuer, fire (9); & jagen, to chase (5) & $\begin{array}{l}\text { erbärmlich, } \\
\text { pitiful (2) }\end{array}$ & Pest, plague \\
\hline \multirow[t]{10}{*}{ Gefahr, peril (10) } & schlecht, bad (6) & $\begin{array}{l}\text { grausam, } \\
\text { horrible (2) }\end{array}$ & reißen, to tear \\
\hline & $\begin{array}{l}\text { verwunden, } \\
\text { to wound (6) }\end{array}$ & hauen, to hew (2) & Sklaven, slave \\
\hline & Asche, ashes (5) & $\begin{array}{l}\text { kläglich, } \\
\text { wretched (2) }\end{array}$ & spoliieren, to spoil \\
\hline & $\begin{array}{l}\text { ersaufen, } \\
\text { to drown (5) }\end{array}$ & $\begin{array}{l}\text { sengen, } \\
\text { to } \operatorname{scorch}(2)\end{array}$ & stürzen, to plummet \\
\hline & rauben, to rob (5) & $\begin{array}{l}\text { strangulieren, } \\
\text { to strangle }(2)\end{array}$ & umkommen, to kill \\
\hline & $\begin{array}{l}\text { Schrecken, } \\
\text { terror }(5)\end{array}$ & $\begin{array}{l}\text { Tyrannei, } \\
\text { tyranny (2) }\end{array}$ & $\begin{array}{l}\text { Verbitterung, } \\
\text { acrimony }\end{array}$ \\
\hline & schwer, difficult (5) & $\begin{array}{l}\text { verheeren, to } \\
\text { devastate (2) }\end{array}$ & verletzen, to injure \\
\hline & Schwert, sword (5) & $\begin{array}{l}\text { verwüsten, to } \\
\text { devastate (2) }\end{array}$ & $\begin{array}{l}\text { Verrätterei, } \\
\text { treacherousness }\end{array}$ \\
\hline & $\begin{array}{l}\text { trennen, } \\
\text { to sever }(5)\end{array}$ & & wüten, to rampage \\
\hline & & & zertreten, to trample \\
\hline
\end{tabular}

Both of the reporting systems that communicate news of Transylvania use words from each frequency category, but with a variation in usage pattern depending on whether the report comes from a reporting centre or from a region that focuses on local news. Words from Category A account for over half of both the 86 uses of this vocabulary of violence from Vienna and the 52 uses in the reports from Prussia (see Fig. 3.2). Meanwhile, the more local branches of each reporting system - Hungary, Transylvania, and Poland - offer 


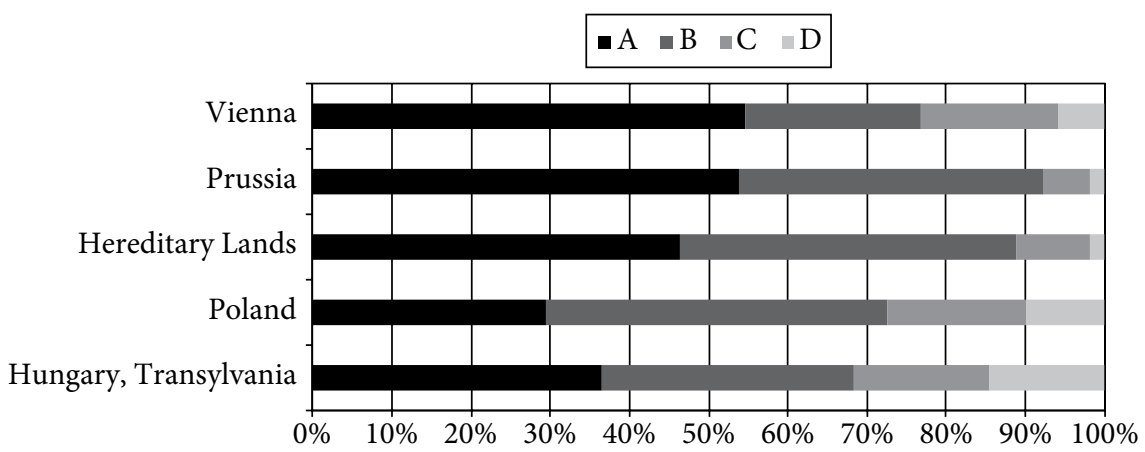

FIGURE 3.2 Distribution of violence vocabulary by frequency category for each major reporting region

slightly more varied vocabulary. Of the 41 violence words which appear in the reports of Hungary and Transylvania, and of the 52 violence words which appear in the reports of Poland, less than $40 \%$ come from Category A and over $10 \%$ are from Category D. Reports from the Hereditary Lands most resemble the news centres in the frequency distribution of violent vocabulary, with $46 \%$ of the 54 word uses coming from Category A and only $2 \%$ coming from Category D.

What is remarkable about the descriptions of violence from the Hereditary Lands is that they occur almost exclusively in the stories about Rákóczi's invasion of Poland. Even though the cities of the Hereditary Lands contribute 21 reports on the events of the Ottoman actions in Transylvania, these stories only contain one occurrence of a single violence word: Ruin. The reports of Rákóczi's march into Poland, on the other hand, contain 55 instances of violence words. Both of the major reporting systems, not unexpectedly, contain more references to the violence of local conflicts. From Prussia-Poland the stories of the Rákóczi's invasion contain 124 instances of violence words, while those of the Ottoman invasion only contain 4. Likewise, the Vienna-Hungary system uses 112 violence words on the military action within Transylvania and only 14 on the Transylvanian aggression in Poland.

However, despite the fact that news of the war in Poland and the news of the war in Transylvania are largely reported from different regions, there is a certain consistency in the language used to describe each conflict's violence. The words from Category A, the most frequently used violence words in these news stories, primarily describe actions such as burning, massacring, and chasing, as well as some of the most fundamental consequences of these actions: 'damage', 'violence', 'ruin', 'fire', and 'peril'. These words appear nearly equally in the 
stories of both the military actions in Poland and the invasion of the Ottomans (see Fig. 3.3). However, the words from Category B are not as equally represented in both stories. These words are used a total of 31 times in the stories from Vienna-Hungary and 42 times in the stories from Prussia-Poland, but this scale is tipped even further when the 23 Category B words from the Hereditary Lands are added. As a consequence, the words from Category B are much more likely to appear in the stories of Poland (see Fig. 3.4), and include words which give more nuance to a narrative. Words for bodily harm include those where a specific weapon or means is implied, as in to 'shoot', 'drown', and 'sever', as well as adjectives describing the seriousness of injury - 'bad', 'difficult', 'severe' and words which indicate a personal, emotional response, such as 'dread', 'threat', and 'terror'.

Each reporting system communicates news of the violence of the most immediate importance to the reporting location: Prussia-Poland tells of the actions of the Transylvanian army in Poland, while Vienna-Hungary details the events which come as a consequence of the Ottoman invasion. This is also true for the news coming from the Hereditary Lands. Though the Hereditary Lands are strongly connected to the city of Vienna - the lands are ruled by the Habsburg Emperor - and though nearly a quarter of their total news reports pertain to events between the Transylvanians and the Ottomans, this is not the news that is seemingly of the most importance to this region. Rather, when this region gives details beyond the basic actions of war, when it conveys dread or severity, or details death by drowning, the news related is of the conflict in

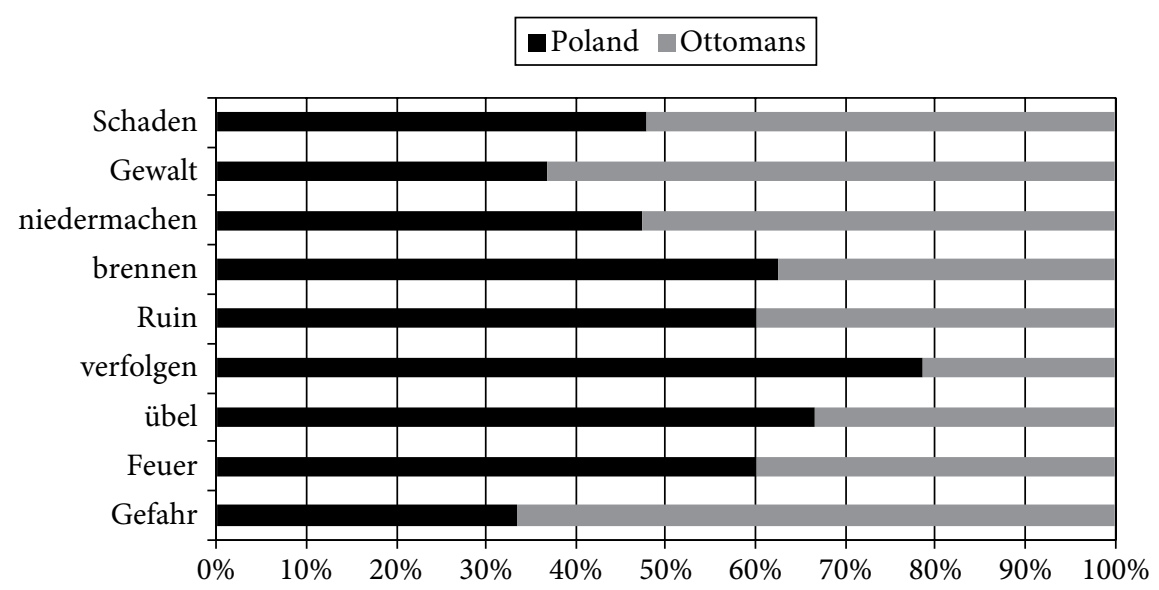

FIGURE 3.3 Distribution of words from Category A between stories about Poland and stories about the Ottomans 


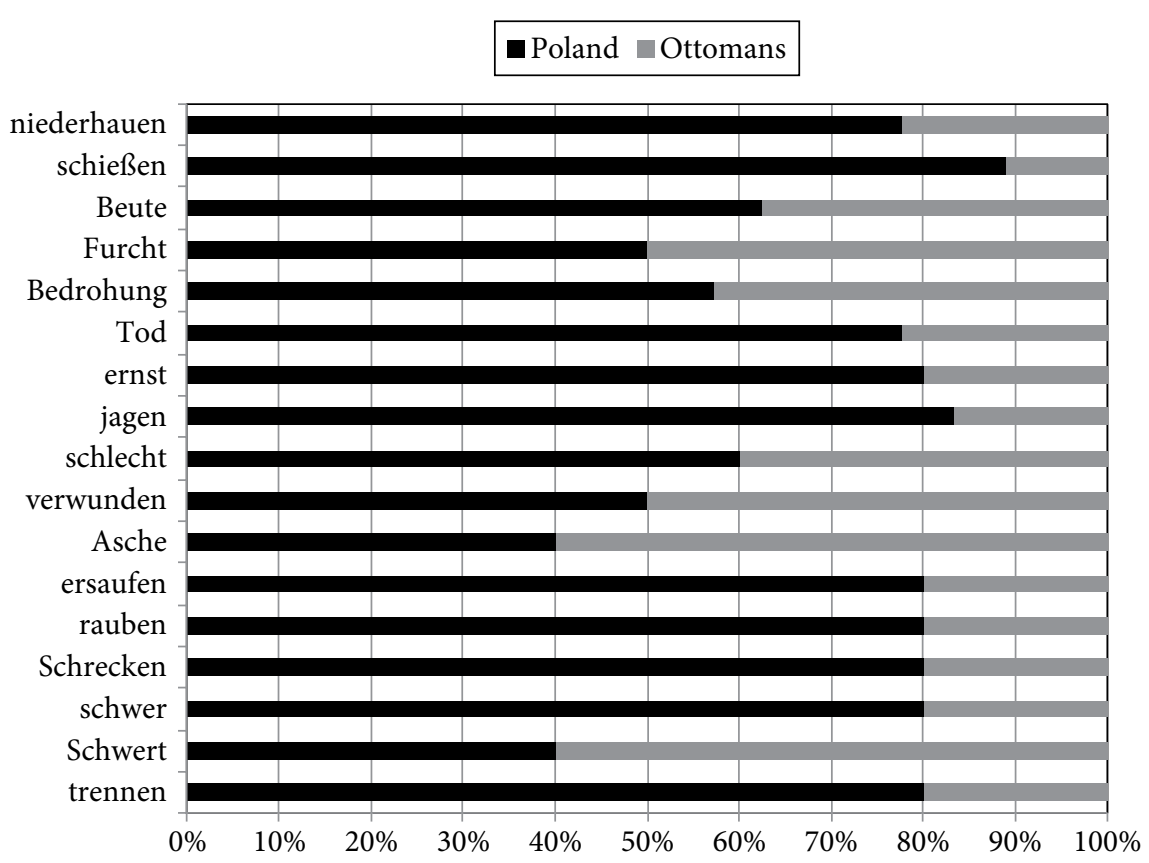

FIGURE 3.4 Distribution of words from Category B between stories about Poland and stories about the Ottomans

Poland, much nearer geographically and of more immediate concern than any Imperial worries about the Turks.

\section{Conclusion}

The news of Transylvania that is communicated in the German language newspapers of 1657-1658, is largely determined by the interests of the reporting systems of Vienna-Hungary and Prussia-Poland. While there are a handful of stories from the principality itself, primarily reporting on actions within the Transylvanian diet, this number is overwhelmed by that of news reports coming from foreign locations, each concentrating on their own local interests. In the reports from Prussia-Poland, accounts are centred on Rákóczi's march into Poland-Lithuania to meet the Swedish army and take the throne. The urgency of this action is underscored by the repeated prayers to God within the text of the reports, as well the language of violence employed, not to communicate the movements of the army, but to describe the killing, plundering, burning, fear, and destruction that results. While the religious language is not continued in 
the reports from the Hereditary Lands, the images of violence are. Though this region has political ties through the Imperial crown to both Vienna and Hungary, its news of Transylvania comes chiefly through Silesia and Breslau, and the cultural and economic ties of the region inspire not only a great deal of communication with Poland-Lithuania, but also a greater apparent interest in the violence of the war in Poland. The reporting system of Vienna-Hungary, on the other hand, reports more frequently on the events within the principality, especially as the government becomes increasingly unstable and the Ottomans march on Transylvania. The violence of these events is still expressed, but rather than supplementing the news with prayers for peace and protection, the reports from Vienna-Hungary call attention to the religious affiliation of the advancing army, emphasizing the fear that if the Ottomans are successful in their attack and Transylvania falls more directly under Turkish control, there will be dire consequences not only for its own city and lands, but for all of Christendom.

\section{Appendix}

\section{Extant Issues of German Language Newspapers from 1657-1658}

Bibliographic information comes from Else Bogel and Elger Blühm, Die deutschen Zeitungen des 17. Jahrhunderts: ein Bestandverzeichnis mit historischen und bibliographiscen Angaben (Bremen: Schünemann Universitätsverlag, 1971-1985).

Titles given are those which act as headings in the above work, with subheadings appearing for the names carried by the newspapers from 1657-1658. When names of the printers are given, they are those who held the position from 1657-1658. Abbreviations designated by the author.

\section{Continuation Deß jüngst zwischen beyde Königliche Schwedische vnd Polnische} Armeen zugetrgenen Kriegs-verlauffs. Frankfurt a. M.: n.p.

Continuation Deßjüngst zwischen beyde Königliche Schwedische vnd

Polnische Armeen zugetrgenen Kriegs-verlauffs.

1657:17, 32

Continuation Deßjüngst zwischen beyden König. Schwedischen/

Polnischen

vnd Dähnenmarckischen Armeen zugetrgenen Kriegsverlauffs.

1658: 1-3, 5-22, 27, 28, 33-37, 39, 40, 47-72, 74, 76-79, 91-107, 109,

112-115, 118-125, 127, 129-135, 136-138

Absonderliche Relation

1658: 59 
Dingstags (Freytags) Particular. Danzig: David Friedrich Rhete

P:Di Dingstags (Dinstags, Dienstags) PARTICULAR

$1657: 45,46,48,50$

1658: 2, 24, 31

P:Fr Freytags PARTICULAR

$1657: 46,47,49,51,51[=52]$

1658: 2, 3, 13, 19

P:Sa Sonnabends PARTICULAR

1657:30, 51

1658: 4,6

Europaiesche Wochentliche Zeitung, Europaeische Ordinari Postzeitung. Königsberg:

Johann Reußner

EWZ Europaeische Wochentliche Zeitung

1657: 45

EWZ:Eop Europaeische Ordinari Postzeitung

1657: 45

EWZ:Do Donnerstags PARTICULAR Zeitung Zur Numer...gehörig

$1657: 36,48,50-52$

1658: II, III, XII, XIX, XXI, XXXXIII

EWZ:Fr Freytags PARTICULAR Zeitung Zur Numer...gehörig

1657: 46, 49

EWZ:So Sontags Europaiescher MERCURIUS

1658: I, III, VI, XI, XXIV, XXX, XXXIIX

EWZ:Sa Sonnabends RELATION, Zum Europaeischen Mercurius Numer...gehörig 1658: V

EWZ:App Europaeischer APPENDIX

1658: V, XV, XX

Europaeische Zeitung. Stettin: Johnann Valentin Rhete

EZ Europaeische Zeitũg

1657: 2, 7, 8, 11, 14

EZ:Ps Particular Schreiben: ...Zun Europaeischen Num. ...1657. Gehörig

1657: 7, 11, 12, No. 1 and 2

EZ:App APPENDIX Europaeischer Zeitungen/von Num...

1657: 2, 7, 8, 11-13, 15, 32-34, 52

EZ:AppPS Particular Schreiben...Zum Appendice Num. ...1657 gehörig

1657: 7, 10, 12-14, 33

EZ:Di Europaeische Dingstägl. Zeitũg

1658: 37,48 
EZ:DiPS Particular-Schreiben:Zu No...Anno...Europaeisher Dingstägl.Zietungen gehörig

1658: 49,50

EZ:Sa Europaeische Samstägl. Zeitũg

1658: 13

Newe Vnpartheysche Zeittung vnd Relation. Zürich: Offizin Bodmer

NZR OrdinariWochenzeitung

1657: I, III-V, X, XIII-XV, XVIII, XX-XXV, XXVII, XXX, XXXII-XXXVIII, XL, XLII, XLIV, XLVI, XLVIII, XLIX, LII, LIII

1658: I-VIII, X-XII, XIV[=XV], XVI-XX, XXII-XLII,

XLIV-XLIX, LI

Ordenliche Wochentliche PostZeitungen. München: Lucas Straub.

Ordentliche Wochentliche Post(-)Zeitungen/dises...Jahrs.

1658: I-XXIII, XXIX-XLV, XLVII-XLX[=L], XLVII-XXXXXI[=LII]

(gaps and repetitions are due to misnumbering)

Ordinari Wochentliche PostZeitungen. Erfurt: n.p.

Ordinari Wochentliche PostZeitungen

1658: 97, 99

Extraordinari einkommene Zeitungen

1658: 98, 102, 104

Ordinari Zeittung. Wien: Mattäus Cosmervius

Extraordinari Mittwochs PostZeittungen

1658: DCCLXIV, DCCXXVIII

Ordinari Zeitung. München: Johann Jäcklin

Mercurij(i)Relation Oder Zeit(t)ungen/von uvderschidlichen Ort(h)en/

Auff das...Jahr

1658: 1-52

Particular Zeitung. n.p.: n.p.

Particular Zeitung

1657: 9, 14-16, 44-46, 51, 53, 54

1658: 1,12

Particular-Zeitung. Danzig: n.p.

1657: 11 
Postzeittungen. Prag: Ludmilla Sedlčanska

Ordinari Wochentliche Mitwochs Postzeittungen

1658: CLXXXVIII

Extraordinari Wochentliche Postzeittungen

1658: CLXXXVII

Post Zeitung. Hamburg: Johann Baptista Vrints

HPZ:M Europaeische Mitwochentliche Zeitung

1657: 6, 9, 17, 28, 35, 41, 42, 48, 49-53

1658: 7, 10, 12, 16, 21, 29, 47

HPZ:Sa Europaiesche Samstägige Zeitung

1657: 15, 21, 22, 27, 29, 42, 46, 50, 52

$1658: 2,3,16,17,28,38,42,47,53$

Raporten. Köln: Caspar Kempen

Ordinari Wochentliche Dinstags Postzeitungen

1657: III

Relation Aller Fürnemmen vnd gedenckwürdigen Historien. Straßburg: n.p.

RAF Zeitung

1657: 18

Titellose Zeitung. Berlin: Offizin Runge

B:O B. Einkommende Ordinar- und Postzeitungen

1658: XXXVIII: III, XXXIX: I, XL: III, LII: I, II

B:E B. Extraordinari(-)Zeitungen

1658: 'Holstein, 6/16. 8., 'Hamburg 13/23. 11.,' 'Holstein 26. 11.,'

'Elbstrom 29. 11.,' 'Stettin 19. 12.'

Titellose Zeitung (Frankfurter Postzeitung). Frankfurt a. M.: Johann Baptist

Höswinkel

OWP Ordentliche Wochentliche Postzeitungen

1657: III, V, VIII, XVIII-XX, XXXVIII, XXXIX

Wochentliche Ordinari-Post-Zeitungen. n.p.: n.p.

Wochentliche Ordinari-Post-Zeitungen

1657:28, [47?]

1658: 2

Wochentliche Zeitung Auß Hamburg. Kopenhagen: Peter Hake

ZAH Wochentliche Zeitung Auß Hamburg

1657: 27, 29, 30, 32-36, Sec. 36, 37-48, Sec. 48, 49, 50 
ZAH:M Mitwochentliche Zeitung

1657: 'Prag 20.9.'

ZAH:H Ordinarie Wochentliche Zeitung auß Hamburg 1658: I

ZAH:D Ordinarie Wochentliche Zeitung/auß Deutschlandt 1658: Sec. 12

ZAH:WR Warhafftige RELATION, Von Unter schiedenen Oertern/aus Deutschlandt 1658: 'Myttauw 6.10.'

ZAH:R RELATIONAus Unterschiedlichen frebden Örten 1658: '16. 11.'

ZAH:ER Europaeische RELATION Auß Unterschiedlichen frembden Oertern. 1658: '15. 12.'

Wöchentliche Zeitung auß mehrerley örther. Hamburg: Martin Schumacher WZ:Di Ordinari Diengstags Zeitung

1657: 1-53

1658: $2-52$

WZ:Do Wochentliche Donnerstags Zeitung

1657: 1-52

1658: 1-52

WZ:App APPENDIX Der Wochentlichen Zeitung Von Numero... 1657:1-52

1658: $1-21,23-52$

The following papers appear in Bogel and Blühm's bibliography but do not appear in my analysis:

Extraordinary Sontags-Zeitung. n. p.: n.p. 1658: 49.

Ordinari Sontags-Zeiutng. n. p.: n.p. 1657: 12. 